\title{
PRZENIESIENIE STOLICY BISKUPIEJ Z CHELMA DO KRASNEGOSTAWU (1490)
}

W ramach działalności kościelnej króla Kazimierza Wielkiego na Rusi halickiej pap. Innocenty VI bulla Dum iuxta z $20 \mathrm{~V} 1358 \mathrm{r}$. zamianowal biskupem chełmskim franciszkanina Tomasza ze Sienna. Według tenoru bulli papieskiej diecezja istniała już dawniej i od śmierci ostatniego biskupa wakowała przez dłuższy czas. Wydaje się jednak, że wakans ten nie był zbyt długi, ponieważ nic nie wiadomo o wcześniejszym istnieniu diecezji. Jeżeli istniała formalnie, to nie weześniej powstała jak po r. $1349^{1}$. Według zaś opinii Wł. Abrahama „treść [...] nominacji wskazuje, że $w$ Chełmie przedtem nigdy jeszcze lacińskiego biskupa nie było" : Bulla ekspedycyjna tejże daty została wysłana do metropolity gnieźnieńskiego, co wskazuje, że dziecezja chełmska miała należeć do jego metropolii. Zgodnie bowiem z supliką królewską z dnia 7 XII 1357 r., wysłaną na dwór papieski w Awinionie do pap. Innocentego VI, wszystkie przyszłe biskupstwa obrządku łacińskiego na Rusi halickiej miały być poddane metropolii gnieźnieńskiej ${ }^{3}$. Pod tą samą datą dołączono bullę do wiernych miasta i diecezji chełmskiej, i osabną do króla Kazimierza ${ }^{4}$.

Te liczne dokumenty papieskie nie erygowały nowej diecezji, ale zgodnie z praktyką przyjęta po czwartej wyprawie krzyżowej w Eacińskim Cesarstwie Bizantyjskim, dokonano tylko obsadzenia hierarchą obrządku lacińskiego istniejącej tu stolicy biskupstwa wschodniego ${ }^{5}$. Jeszcze bowiem w dniu 19 VI 1372 r. pap. Grzegorz XI polecił biskupowi krakowskiemu Florianowi Mokrskiemu usunięcie biskupów wschodnich z zajmowanych stolic biskupich na Rusi halickiej ". Taka zresztą wówczas panowała koncepcja przywrócenia jedności między chrześcijaństwem wschodnim a zachodnim, wypracowana w okresie czwartej wyprawy krzyżowej. Radykalnie miał ją zmienić dopiero w 1439 r. sobór florencki. s. $130 \mathrm{n}$.

1 B. Kumor: Granice metropolii $i$ diecezji polskich 968-1939. Lublin 1969-1971

2 W. Abraham: Powstanie organizacji Kosciola lacińskiego na Rusi. T. 1. Lwów 1904 s. 244.

8 B. Kumor: Granice metropolii (halickiej) lwowskiej w okresie przedrozbiorowym. Prawo kanon. R. 11: $1968 \mathrm{nr} 1 / 2 \mathrm{~s} .5 \mathrm{n}$.

- W. Abraham: dz.c. Dodatki nr 6 s. $371-373$.

$\checkmark$ J. Hajjar: Zwischen Rom und Byzanz. Die unierten Christen des Nahen Ostens. Mainz 1972 s. $112 \mathrm{nn}$.

6 Vet. Mon. Pol. Lith. I nr 910 s. 676. 
Biskupstwo wschodnie $w$ Chelmie istniało $z$ całą pewnościa $w 1235$ r., kiedy to ksiazzę Daniel Halicki zbudowal nowy gród chełmski, przeniósił doń stolicę księstwa i zarazem udotowal biskupstwo $\mathrm{z}$ katedrą św. Jana? W drugiej polowie XIV w. biskupstwo chelmskie ob. wschod. było absadzone, a w 1371 r. zostało podporządkowane reaktywowanef przez krola Kazimierza wschodniej metropolii halickiej ${ }^{\circ}$. Toteż biskupstwo łącznie ze swoją katedra i terytorium mialo stanowić $w$ planach kurii awiniońskiej łacińskie biskupstwo chełmskie. Ale diecezja faktycznie pozostawała $w$ rękach Kościoła wschodniego. Stąd też nominacja łacińskiego hierarchy na Chelm w osobie biskupa Tomasza z Sienna miala charakter formalny, a nie faktyczny, a biskup Tomasz nigdy diecezji $w$ posiadanie nie objąl. Zresztą Chełmszczyzna wowczas pod względem politycznym należała do Litwy i dopiero w r. 1366 na prawie lenna została przyłączona do Polski. Pracowal on natomiast $w$ charakterze biskupa pomocniczego w diecezji krakowskiej, gdzie zmarł po r. $1365^{9}$.

Dopiero kiedy król Kazimierz Wielki w oparciu o patriarchat ekumeniczny w Konstantynopolu odnowił w 1371 r. hierarchię Kościoła wschodniego na Rusi halickiej, wówczas to doszło do formalnej erekcji biskupstwa ob. łac. w Chełmie, ale stało się to już za rządów ks. Władysława Opolczyka. Uczynil to pap. Grzegorz XI na mocy bulli Debitum pastoralis officii z dnia 13 II $1375 \mathrm{r} \cdot{ }^{10}$ Ale $i$ tym razem formalnie utworzona diecezja nie posiadała ani uposażenia, ani katedry, ani też ściśle wyznaczonego terytorium; to ostatnie prawdopodobnie pokrywało się z granicami biskupstwa wschodniego. Zreszta sama Ziemia Chełmska dopiero w 1387 r. została inkorporowana bezpośrednio do Polski ${ }^{11}$. Toteż, mimo formalnej erekcji papieskiej, biskupstwo lacińskie w Chelmie miało nadal charakter faktycznie tytularny, a drugi z rzędu biskup chełmski Stefan po $1386 \mathrm{r}$. pełnił funkcje biskupa pomocniczego $\mathrm{w}$ diecezji poznańskiej, kamieńskiej i włocławskiej. Zajął się on organizacją swej diecezji dopiero w latach 1403-1406. Po jego śmierci diecezją administrowal przez pewien czas metropolita halicki ob. łac. Jakub Strepa. Następnie cała diecezja została wchłonięta przez biskupstwo włodzimierskie, a w dokumencie unii polsko-litewskiej z $2 \times 1413$ r. biskupstwo akreślono jako "waku jące" ${ }_{12}$.

Faktycznym fundatorem biskupstwa stał się król Władysław Jagiełło, który na prośbę biskupa Jana Biskupca i jako dziękczynienie za zwycięstwo grunwaldzkie w dokumencie z 14 VIII 1417 r. uposażyl biskupstwo

1 B. Zimmer: Miasto Chelm. Zarys historyczny. Warszawa 1974 s. 16; A. Poppe (Organizacja Kosciola (Rus). W: Slow. Starożyt. Słow. T. 3. Wroclaw 1967 s. 514) przyjmuje, ze biskupstwo chelmskie powstalo ok. $1220 \mathrm{r}$. W Uhrusku, a następnie zostalo przeniesione do Chelma.

8 J. Fijałek: Biskupstwa greckie $w$ ziemiach ruskich od polowy XIV $w$. Kwart. hist. R. 11: 1897 s. 34 nn.; Z. Kaczmarczyk: Monarchia Kazimierza Wielkiego. Poznan 1946 s. 118.

9 W. Abraham: dz.c. s. 245.

10 Vet. Mon. Pol. Lith. I nr 964 s. 713; Documenta Romanorum Pontificum res gestas Ucrainae illustrantia. Vol. 1. Romae $1954 \mathrm{nr} 58$ s. 94-97 podaje, ze stako ste to na mocy bulli tegoź papieża Dudum siquidem z 13 II 1375; por. B. Kumor: Granice metropolii s. $131 \mathrm{n}$.

${ }_{11}$ W. Cwik, J. Reder: Lubelszczyzna. Dzieje rozwoju terytorialnego, podziatów administracyjnych i ustroju wtadz. Lublin 1977 s. 23; B. Zimmer: dz.c. s. 23.

12 B. Kumor: Granice metropolii s. 131. 
kilkoma wsiami wraz z immunitetem gospodarczym. W dwa lata pónniej (5 VII 1419 r.) uposażenie to powiększył ${ }^{12 a}$. Toteż zapewnienie podstaw materialnych diecezji $i$ jej centralnym instytucjom ustabilizowało jej byt i rozwój na przyszłość. Już w 1417 r. istniała w Chełmie katedra biskupa lacińskiego pw. Najśw. Maryi Panny i Rozesłania 12 Apostolów, zbudowana przez króla Jagiełłe „, in signum felicis victoriae" pod Grunwaldem; zwycięstwo bowiem grunwaldzkie przypadło w. uroczystośc liturgiczna Rozesłania 12 Apostołów (15 VII) ${ }^{18}$. Obok katedry istniał w mieście kościół parafialny pw. Wniebowzięcia Najśw. Maryi Panny, zbudowany ok. $1392 \mathrm{r}$. W związku $\mathrm{z}$ przeniesieniem miasta $\mathrm{z}$ prawa polskiego na niemieckie $^{14}$. W $1424 \mathrm{r}$. funkcjonował $\mathrm{w}$ diecezji już oficjałat i wikariat generalny, a w 1427 r. mamy wzmianki o istnieniu kancelarii biskupiej ${ }^{15}$. Wreszcie dzięki niezwykle czynnej działalności duszpasterskiej biskupa-organizatora Jana Biskupca do 1452 r. w diecezji było czynnych ok. 40 parafii, $z$ czego za jego pontyfikatu powstało ponad 20. Osiągnięciem wysokiej klasy biskupa było zorganizowanie i odbycie aż czterech synodów diecezjalnych ${ }^{10}$. Wreszcie na skutek osobistych zabiegów biskupa Biskupca król Jagiełło dokumentem z 12 VII 1429 r. udotowal kapitułę chełmską (2 pralatów i 10 kanoników gremialnych) "

Również długie lata panowania kxóla Kazimierza Jagiellończyka były dla rozwoju diecezji pomyślne. Wystarczy tu wspomnieć pomnozenie uposażenia biskupstwa (1452), nadanie pewnych przywilejów kapitule i nowych posiadłości $(1456,1463)$, powiększenie uposażenia biskupstwa (1470) i kapituły (1472), czy wreszcie potwierdzenie dotychczasowych przywilejów biskupstwa i kapituły (1485) ${ }^{18}$.

W $1473 \mathrm{r}$. miasto poniosło poważne straty na skutek pożaru. Nie znamy bliżej rozmiarów szkód wyrządzonych przez ogień, ale moźna przypuszczać, że niezwykła susza panująca w ówczesnej Polsce, która powodowała liczne pożary lasów, miast i wsi, sprzyjała większym szkodom i. zniszczeniom pożarowym ${ }^{2}$. Nie jest wykluczone, że ofiarą płomieni padła również katedra łacińska, jako że była zbudowana z drzewa. Sam Chełm w XV wieku nie był miastem dużym, a pożar przyczynił się jeszcze bardziej do jego zniszczenia. Jan Długosz w swej geografii ziem polskich pisze dosłownie, że ,miasto znane tylko z zamku i stolicy bisku-

12a W. Abraham: Akt fundacyjny króla Wladystawa Jagietty dla biskupstwa chetmskiego. Kwart. hist. R. 32: 1918 s. 473-478; L. Bierkowski: Dziatalnosc organizacyjna biskupa Jana Biskupca w diecezji chelmskiej (1417-1452). Roczn. human. R. 7: 1958 z. 2 s. 200 n.

1s L. Bieńkowski: dz. c. s. $224 \mathrm{n}$.

14 B. Zimmer: dz, c. s. 212 (tekst dokum. lokac.); L. Bieńkowski: dz. c. s. $225-226$.

16 L. Bieńkowski: dz. c. s. 202 n.

16 J. Sawicki: Najdawniejsze statuty synodalne diecezji chelmskiej $z$ XV 20. Lublin $1948 \mathrm{~s}, 14 \mathrm{nn}$; L. Bieñkowski: dz. c. s. 222.

17 P. Kalwa: Przywilej fundacyjny krola Wladyslawa Jagielty dla kapituty chelmskiej $z$ r. 1429. Kwart. hist. R. 47:1933 s. 73-77; P. Pałka: Powstanie katedralnej kapituly obrzqdku lacińskiego w Chelmie i przeniesienie jej do Krasnegostawu. Roczn. teol.-kanon. R. 17: 1970 z. 5 s. 15-19.

18 ADL (Archiwum Diecezjalne $w$ Lublinie) A 157. Decreta reformationum a R.D. J.E. Szembek episcopo Chelmensi et aliis episcopis Chelmensibus ex annis 1694-1751 lata s. 907: Summarium privilegiorum Capitulf Chelmensis [...] 1749 connotatum.

19 J. Dlugosz: Historiae Polonicae libri XII. Ed. A. Przezdziecki. T. 5. Cracoviae 1878 s. 596 n.; B. Zimmer: dz. c. s. 41; K. Czernicki: Chetm. Przeszlośc $i$ pamiqtki. Chelm 1936 s. 13. 
piej, jest w zupełnym upadku i mało znane do tego stopnia, że stolice biskupią należałoby przenieść do Hrubieszowa, miasta o większej liczbie mieszkańców i lepiej urządzonego" 20 . Ale zdaje się, że i przed pożarem miasta jego sytuacja gospodarcza musiała być nie najlepsza, skoro biskup Biskupiec juz w 1424 r. podjał starania o przeniesienie stolicy biskupiej do Lublina i włączenia całej Lubelszczyzny do diecezji chełmskiej. Plany te, które otrzymały już sankcję króla Jagiełły i Stolicy Apostolskiej, zalamały się na skutek zdecydowanego sprzeciwu biskupa krakowskiego Zbigniewa Oleśnickiego ${ }^{21}$.

Do projektu przeniesienia stolicy biskupiej z Chelma powrócil $w$ drugiej połowie XV w. biskup Pawel z Grabowej (14 VI 1463-18 VI 1479) i podjął sugestie Długosza ${ }^{22}$. Hrubieszów, który w planach biskupa Pawła mial być nową stolicą biskupstwa chełmskiego, był miastem bardziej ludnym, lokację na prawie niemieckim otrzymal w 1440 r., a w mieście obok kościoła parafialnego pw. Wniebowzięcia Najśw. Maryi Panny, udotowanego w $1400 \mathrm{r}$., istniał nadto kościół i klasztor dominikanów pw. sw. Mikołaja ${ }^{23}$. Samo miasto, chociaż leżało przy nowym szlaku handlowym, lączącym Lwów ze Sląskiem i Wielkopolską, położone było bardziej centralnie w stosunku do terytorium diecezji. Zabiegi biskupa Pawła u króla Kazimierza miały pozytywny skutek. Wzmiankowane uprzednio dokumenty, wystawione przez króla na korzysć biskupstwa chełmskiego, kazały się spodziewać takiego wyniku starań. Dokumentem z dnia 28 IV 1473 r. król zgodził się na translacje stolicy biskupiej z Chelma do królewskiego miasta Hrubieszowa.

Dokument translacyjny znany jest ze współczesnej kopii, ingrosowany do Metryki Koronnej, a także z XVI-wiecznej kopii; później kopii tych sporządzono więcej ${ }^{24}$. Ale trzeba przyznać, że jego formularz i słownictwo odbiegają nieco od formularzy dokumentów Kazimierza Jagiellończyka. Dokument został wystawiony w Lublinie w dniu 28 IV 1473 r. Według relacji Długosza król Kazimierz rzeczywiście od Niedzieli Białej tegoż roku przebywał w Lublinie, gdzie wystawił kilka dokumentów ${ }^{25}$. Lista świadków dokumentów nie budzi zadnych zastrzeżeń. Większa ich część była również z królem Kazimierzem w Piotrkowie, dokąd król się udał z Lublina. Sam zresztą wystawca dokumentu, ks. Zbigniew Olesnicki przed 12 XI 1472 r. został podkanclerzym koronnym ${ }^{20}$. Trzeba więc przyjąć, że dokument, mimo pewnych wątpliwości, jest autentyczny.

W rzeczonym dokumencie król Kazimierz, na prośbę biskupa chełmskiego Pawła z Grabowej i kapituły chełmskiej, postanowił:

$1^{\circ}$ przenieść stolicę biskupią z Chelma do królewskiego miasta Hrubieszowa „,bardziej ludnego", po uzyskaniu uprzedniej zgody Stolicy Apostolskiej;

20 J. Dlug.osz: dz. c. T. 1. Cracoviae 1874 s. 52 n.

21 Z. Starnawski: Źródta do sporu o przynależność diecezjalnq powiatu lubelskiego w XV wieku. Roczn. teol.-kanon. T. 11:1964 z. 4 s. 157-183; B. Kumor: Granice metropolii s. 133 .

${ }_{22}$ Z. Szostkiewicz: Katalog biskupów ob. lac. przedrozbiorowej Polski. Rzym 1954 s. 70.

2s Miasta polskie w Tysiącleciu. T. 1. Wrocław 1965 s. 706; L. Bieńkowski: dz. c. s. $233-235$.

24 Zob. Dodatki nr 1.

25 J. Dlugosz: dz. c., t. 5 s. 582; Matr. Reg. Pol. Summ. Pars I nr 1005-1009 s. 52.

20 J. Korytkowski: Arcybiskupi gnieznienscy, prymasowie i metropolici polscy. T. 2. Poznán 1888 s. 451 . 
$2^{\circ}$ na katedre biskupią przeznaczał hrubieszowski kosciół parafialny pw. 'Wniebowzięcia Najśw. Maryi Panny, który odtąd miał nosić tytuł Rozesłania 12 Apostołów oraz św. Stanisława Biskupa i Męczennika; ska";

$3^{\circ}$ odtąd diecezja miala nazywać się nie "chełmska”, ale „hrubieszow-

$4^{\circ}$ równocześnie inkorporowal beneficjum parafialne w Hrubieszowie do masy majątkowej prepozyta kapituły chełmskiej, zobowiązując go do utrzymania trzech wikariuszy dla pracy duszpasterskiej;

$5^{\circ}$ oddal na własność biskupstwa „omnem locum et spatium" w Hrubieszowie celem wystawienia odpowiednich budynków dla konsystorza biskupiego, kapituły katedralnej i wikariuszy.

Ale mimo wydania dokumentu królewskiego translacja stolicy biskupiej i zmiana nazwy diecezji nie doszła do skutku, chociaż wielu autorów przyjmuje ja jako fakt pewny ${ }^{27}$. Wielu badaczy zadowala się stwierdzeniem, że "racje [dlaczego nie przeniesiono stolicy biskupiej] i dzisiaj trudno jest ustalić" ${ }^{28}$. Tymczasem wydaje się, że jedną z tych racji, iż stolica diecezji pozostała nadal $w$ Chełmie i diecezja nadal nazywała sie "chełmską", były przyjęte już w XI stuleciu przepisy prawa kościelnego, które zastrzegały wyłącznie papieżowi przenoszenie stolic biskupich i zmianę nazw diecezji. Te formy prawne w XIV stuleciu określił jeszcze raz $\mathrm{w}$ dekretach pap. Jan XXII w $1317 \mathrm{r.}^{29}$. Dokument królewski z $1473 \mathrm{r}$. wyraźnie stwierdzał, że zarówno translacja stolicy biskupiej, jak też zmiana nazwy diecezji jest uzależniona od uprzedniej zgody Stolicy Apostolskiej. Bez zgody tej Stolicy nie można było przenieść ani stolicy biskupiej, ani też zmienić nazwy diecezji. Zabiegi w Rzymie o uzyskanie odpowiedniej zgody i dokumentu pap. Sykstusa IV (9 VIII 1471-12 VIII 1484) były z góry skazane na niepowodzenie, jako ze król Kazimierz Jagiellończyk od dłuższego czasu pozostawał w konflikcie ze Stolicą Apostolską na tle obsady biskupstw w Polsce, zatwiendzenia II pokoju toruńskiego, spraw czeskich i ekstradycji Filipa Kallimacha. Za pontyfikatu pap. Sykstusa IV konflikt między dworem królewskim w Polsce a papieskim Rzymem rozgorzal do tego stopnia, że $w$ maju 1478 r. poseł królewski, kanonik poznański Jan Gosłupski zagroził papieżowi w imieniu króla formalnym oderwaniem Kościoła polskiego od Stolicy Apostolskiej ${ }^{30}$. W takiej sytuacji nie mogło być mowy o pozytywnym załatwieniu w Rzymie sprawy translacji stolicy biskupstwa chelmskiego.

Sytuacja ta zmienila się wyraźnie na korzyść Polski za pontyfikatu pap. Aleksandra VI, co m.in. potwierdzały prekonizacja papieska 20-letniego syna królewskiego Fryderyka na biskupstwo krakowskie (24 I 1489), jego promocja kardynalska (20 IX 1493), a następnie przy zatrzymaniu Krakowa obdarzenie go arcybiskupstwem gnieźnieńskim ${ }^{31}$. To zbliżenie polskiego dworu królewskiego do papieskiego Rzymu dawało tym razem lepszą nadzieję na uregulowanie stałej rezydencji biskupów chełmskich.

27 Zestaw autorów - zob. P. Pałka: dz. c. s. 20 n.

28 P. Pakka: dz. c. s. 23.

20 W. M. Plöchl: Geschichte des Kirchenrechts. Bd 3. Aufl. 2. Wien 1962 s. 129; S. M. Kuczyński: Kazimierz Andrzej Jagiellończyk. W: Pol. Słow. Biogr. T. 12. Wroclaw $1966 / 67$ s. $269-273$.

20 L. Pastor: Geschichte der Päpste. Aufl. 4. Bd 2. Freiburg i.B. 1904 s. 622.

31 H. Rybus: Fryderyk Jagiellonczyk. W: Pol. Słow. Biogr. T. 7. Warszawa 1948-1958 s. $167-169$; L. Pastor: dz. c. Bd 3 s. 319. 
Ponowna propozycja $w$ tym zakresie wyszła od nowego biskupa chelmskiego Macieja ze Starej Łomży. Ten dawny sekretarz królewski (1469-1479) i poseł $w$ wielu legacjach, a następnie biskup kamieniecki na Podolu (1483-1490) i od 1490 r. równocześnie biskup chełmski zakrzątał się wkrótce po prekonizacji papieskiej na Chełm (14 V 1490) o odpowiedni dokument królewski ${ }^{22}$. Tym razem król wyznaczał na rezydencję biskupa $i$ stolice diecezji królewskie miasto Krasnystaw, a na katedrę - parafialny kościół WW. Swiętych patronatu królewskiego. Ponieważ dotychczasowa rezydencja biskupa i katedra chelmska miescily się w mieście królewskim i miały być przeniesione do miasta królewskiego, dlatego był wymagany do tej akcji konsens królewski.

Krasnystaw, lokowany w 1394 r. przy drodze handlowej Lwów Lublin i dalej na Sląsk i do Wielkopolski, rozwinąl sie jako miasto $w$ XV stuleciu. Podczas gdy Chełm w $1564 \mathrm{r}$. liczył 112 rzemieślników, to Krasnystaw mial ich 154 (1578). Szacuje się, że w $1565 \mathrm{r}$. Chelm zamieszkiwało 1995 mieszkańców, a samo miasto liczyło 399 domów. Krasnystaw liczył wówczas 1905 mieszkańców i posiadał tyleż domów ${ }^{a s}$. Ale rozwój gospodarczy i kulturalny Krasnegostawu zapowiadal się na przyszłość pomyślniej niż Chełma. Dośc wspomniec, ze w $1749 \mathrm{r}$. parafia katedralna w Krasnymstawie liczyła 4200 wiernych ob. lac., zaś dawna parafia katedralna w Chelmie tylko 1800 osób $^{\text {* }}$. W Krasnymstawie obok parafialnego kościoła pw. WW. Swiętych byl w XV w. kościól i klasztor augustianów pw. Trójcy Przenajśw., fundacji króla Władysława Jagiełly $z$ końca XIV stulecia ${ }^{85}$.

Translacyjny dokument królewski, wydany w Krakowie w czasie trwania sejmu (26 VI 1490) stwierdza, że przeniesienia stolicy biskupstwa z Chełma do Krasnegostawu domagaja się:

$1^{\circ}$ przepisy prawa kościelnego, które postulują, aby stolice diecezji były w większych miastach;

$2^{\circ}$ upadek znaczenia gospodarczego i kościelnego miasta Chelma;

$3^{\circ}$ oraz prośby biskupa elekta Macieja ze Starej Łomży.

Ponieważ dwie ostatnie przyczyny już znamy, dlatego warto przyjrzeć się bỉiżej pierwszej. Prawodawstwo kościelne starożytnego Kościoła, formowane jeszcze'w złotym okresie patrystycznym, na które powoluje się dokument królewski, postulowało na powszechnie uznanym synodzie w Sardyce (343), by diecezji nie tworzono na wsiach, czy w małych miasteczkach „ne vilescant nomen episcopi et auctoritas”, lecz tylko w większych miastach. Kanon ten poprzez zbiór Izyldora z Sewilli dostal się do obowiązującego w XV w. w Kościele zachodnim prawa kościelnego ${ }^{38}$. Do tego też zapewne przepisu odwoływał się dokument królewski.

Zasadnicza część dokumentu z $1490 \mathrm{r}$. wyrażała zgodę na przeniesienie stolicy biskupiej z Chelma do Krasnegostawu, o ile na to zgodzi sie Stolica Apostolska, a także na lokalizację katedry chelmskiej w świątyni parafialnej w Krasnymstawie. Równocześnie król dokonał inkorporacji beneficjum parafialnego $w$ Krasnymstawie do masy majątkowej kolegium wikariuszy katedralnych i zobowiązal tych ostatnich do odbywania

32 I. Sułkowska-Kuraś: Maciej ze Starej Łomży: W: Pol. Słow. Biogr. T. 19. Wroclaw 1974 s. $36-37$.

s3 Miasta polskie t. 1 s. 701, 714; B. Zimmer: dz. c. s. 31.

s4 ADL A 157 Decreta [...] Index k. 1, 2 nlb.

so L. Bieńkowski: dz. c. s. 235-237.

so C. Hefele: Conciliengeschichte. Aufl. 2. Bd 1. Freiburg 1. B. 1873 s. 378, 383. 
oficjum chórowego, jak to był zwyczaj w innych kosciołach katedralnych $w$ Polsce.

Wspomniano już uprzednio, ze od XI wieku Stolica Apostolska rezerwowałá wyłącznie dla siebie przenoszenie stolic biskupich, zmianę granic diecezjalnych, czy też nazwy diecezji. Nie znany nam jest bliżej odpowiedni dokument papieski, potwierdzający translację stolicy biskupiej do Krasnegostawu. Ale taki dokument musiał byc, skoro wszystkie procesy informacyjne biskupów chelmskich z XVI-XVIII w., prowadzone $z$ reguły przez nuncjuszy papieskich $w$ Warszawie, informowały, ze stolica diecezji chelmskiej jest $\mathrm{w}$ Krasnymstawie. Tak $w$ procesie informacyjnym biskupa Stanisława Gomolińskiego z 1591 r. powiedziano, ze , kościół katedralny był niegdyś w Chelmie, ale około 150 lat temu zostal dla większej wygody przeniesiony do Krasnegostawu i tam dotąd się znajduje" "

Warto jednak zauważyć, ze przy akceptacji przez Stolicę Apostolską faktu translacji stolicy biskupstwa, nazwa diecezji pozostała nadal ta sama. Podobny wypadek zaszedł pod koniec XIV w., kiedy pap. Bonifacy IX zgodził się na translacje stolicy diecezji lubuskiej do Fürstenwalde (10 III 1391), przy zachowaniu dotychczasowej nazwy diecezji ${ }^{3 *}$. Identyczny zresztą wypadek zaistniał $w$ późniejszych dziejach samej diecezji chełmskiej. Kiedy 11 VII 1789 r. Sejm Czteroletni zaproponowal inkorporacje województwa lubelskiego do diecezji chełmskiej i zamianę nazwy diecezji na "chełmsko-lubelska”, pap. Pius VI zaakceptowal wlączenie Lubelskiego do diecezji, ale pozostawił jej dawną nazwę "chelmska" so.

Nowa katedra diecezji chełmskiej w Krasnymstawie pw. Wszystkich Swiętych była również drewniana. Zostala ona zbudowana ok. $1394 \mathrm{r}$. (zapewne w związku z lokacja miasta na prawie niemieckim). Po przeniesieniu katedry biskupiej do Krasnegostawu swiątynia otrzymała tytuł Wszystkich Swiętych i Rozesłania 12 Apostołów. Przy tej świątyni, zastąpionej później murowanym kościołem, była katedra biskupia do $1781 \mathrm{r}$., kiedy to biskup Wojciech Skarszewski przeniósł katedrę do pojezuickiej swiątyni pw. Sw. Franciszka Ksawerego. Uposażenie parafii, obejmującej w 1416 r. 2 łany ziemi, miało odtąd stanowić masę majątkową kolegium wikariuszy katedralnych ${ }^{40}$.

Zachodzi jeszcze pytanie, kiedy faktycznie nastąpiła translacja stolicy biskupiej do Krasnegostawu? Wydaje się bowiem, że nie stało się to $\mathrm{w}$ 1490 r. Jeszcze bowiem w dniu 9 I 1494 r. król Jan Olbracht, na prośbe biskupa chelmskiego Macieja ze Starej Łomży, zgodził się na zakup przez tegoż biskupa dwóch domów w Krasnymstawie dla wikariuszy katedralnych i ponownie wyraził zgode na przeniesienie stolicy biskupiej z Chełma do tego miasta ${ }^{41}$. Zdaje się, iż to wówczas otrzymano potrzebną bgodę Stolicy Apostolskiej i że to właśnie w tym roku nastąpiło ostateczne przeniesienie katedry, kapituły i konsystorza biskupiego z Chełma do Krasnegostawu.

${ }^{a 7}$ Excerpta ex libris manu scriptis Archivi Consistorialis Romani. Ed. J. Korzeniowski. Cracoviae 1890 s. 20.

38 Acta Bonifacii IX. Fasc. 1 (1389-1391). Ed. E. Długopolski. Kraków 1939-1946 nr 199 s. 190-191; por. A. Weiss: Organizacja diecezji. lubuskiej w średniowieczu. Lublin 1977 s. 64.

30 B. Kumor: Granice metropolii s. 218.

40 P. Palka: dz. c. s. 25.

41 Codex epistolar is saeculi decimi quinti. Exd. A. Lewicki. Kraków. 1894 t. 3 s. 414-416; Matr. Reg. Pol. Summ. Pars II (Varsaviae 1907) nr 292 s. 18. 


\section{DOKUMENTY}

$\mathrm{Nr} 1$

Lublin, 28 IV 1473

Kazimierz III król polski, na prośbę biskupa chelmskiego Pawla z Grabowej, przenosi stolice $i$ katedre biskupia $z$ Chelma do Hrubieszowa, zmienia nazwe diecezji na ,hrubieszouska", a katedrze biskupiej w Hrubieszowie nadaje tytuł Rozestania 12 Apostołów i św. Stanistawa B. i M., zastrzegajqc jednakże ostatecznq decyzje w tym względzie Stolicy Apostolskiej.

Or. nie znany.

Kop. 1. Warszawa. AGAD, Metryka Koronna, t. 12 k. 139-140; tytut wpisu: Transiacio ecclesie Chelmensis in Rubieschow oppidum facta. Kopia wspótczesna. Publikacja niniejsza wig tej kopit.

Kop, 2. Lublin. ADL Zesp. Kapit. Chelm. nr 10: Privilegia et jura praecipua ecclesiae cathedralis Chelmensis - _ - k. 21-22'; tytut wpisu: Privilegium XI. Translatio sedis episcopalis I - 1473 (kopia $z$ XVI w.).

Kop. 3. Lublin. ADL Zesp. Kapit. Chelm. nr 9. Elenchus nominum - - ecclesiae cathedralis Chelmensis - - 1754 k. 21'-23; tyt. wpisu: Privilegium XI Translationis sedis episcopalis.

Reg. Matr. Reg. Pol. Summ. Pars I nr 1007 s. 52.

Liter. P. Patka: Powstanie katedralnej kapituly s, 20-23.

In nomine Domini Amen. Ald perpetuam rei memoriam. Principi Regum terre, qui sempiternus regnat in celis perpetuaque mundum racione gubernat, et a regibus et principibus mortalibus culminis fastigio pre ceteris sublimatis exhibenda sunt devocionis pie et religionis, iugi studio, obsequia, et ad id omnis eorum impendendus est conatus, que et decus Majestatis Divine fideique et religionis christiane cultum diffundant et amplificent, et regnorum atque principatuum, illorum regimini creditorum, subministrent profectum.

Proinde Nos Casimirus tertius Dei gracia rex Polonie etc. ${ }^{1}$ Significamus etc. ${ }^{2}$ Qualiter Serenissimi Principis Domini Wladislai, olim Polonie regis; genitoris Nostri carissimi ${ }^{3}$ attendentes opus celeberrimum et insigne, fundacionem videlicet et dotacionem pontificalis ecclesie Chelmensis, quod in signum gratituldinis et fervide sue in Deum ldevocionis, post consecutam de hostibus tunc suis Cruciferis de Prussia famosam victoriam, scitus est ardenti zelo edidisse, edicans illam et intitulans Dueodecem Apostolorum sacratissimo numero, in quorum Divisionis die credidit se, eorum suffragio, triumphum magnificum retulisse ", languidum incrementum atque tenue ob loci desertitudinem, infrequenciam et ariditatem nactum esse. Nos illius ecclesie sortem et condicionem satagens efficere uberiorem et adiicere ei felicius incrementum, ipsam de loco sue fundacionis primarie, civitate videlicet Chelmensi, ob causas supra scriptas, pre-

1 W kop. 2-3: Magnus dux Lithuaniae, Russiae, Prussiaeque Dominus et haeres.

2 Kop. 2-3: tenore praesentium, quibus expedit, universis tam praesentibus, quam futuris.

3 Wladystaw Jagielto król polski (1386-1432). Wzmianka o dokumencie fundacyjnym biskupstwa chetmskiego, wystawionym przex́ tegoż króla $w$ dniu 14 VIII $1417 r$.

- Zwycięstwo grunwaldzkie przypadto $w$ dniu 15 lipca 1410 r., w uroczystość liturgicznq Rozestania 12 Apostotów. Katedra chelmska pw. Rozestania 12 Apostolow byta fundacjq wotywnq. 
ter quas durum et difficile videbamus illic residenciam tam pontificis, quam prelatorum et canonicorum eius, pro qua sepe frustra sudatum est proventuram, in oppidum nostrum regium Hrubyeschow in terra nostra Chelmensi, non longe a duobus fluuiis Bog videlicet et. Huczew situm, ferax, frequens et cultum, fere in meditulio diecesis episcopatus prefati positum, ad honorem Omnipotentis Dei et [k. 140] Gloriosisiime Matris eius Virginis Marie, ac totius hierarchie celestis, et in fidei sancte propagacionem, exterminacionem schismatum et heresum, Regnique nostri Polonie, sub cuius dicione et infra cuius terminos diecesis ipsa consistit, amplitudinem, profectum et decorem, Reverendi Patris Domini Pauli de Grabowa episcopi.5. et sui Venerabilis Capituli. Chelmensis precibus et crebris interpollacionibus permoti, transferendam duximus.

Et in eius translacionem et transposicionem auctoritate Summi Pontificis, in locum prefatum Hrubyeschow, velu't magis habitabilem et insignem fiendam, de certa nostra et ultronea sciencia consentimus, et quantum in nobis est, ipsam transferimus et translocamus, honori et titulo prefatorum Duodecem Apostolorum sacratissimo collegio et numero, nec non et beatissimo Stanislao Martiri et Pontifici Cracouiensi glorioso, Regni quoque nostri Polonie patrono, et suffragatori magnifico, dicendam et insigniendam. Amplius quoque et decetero veteri nomine, quo Chelmensi appellari consueverat abolito, Hrubyeschoviensem nuncupandam, titulandam et vocitandam, et omni honore, titulo, ritu et ceremoniis pontificalibus atque charismatibus prosequendam.

Pro cuius eciam ampliori subsistencia et profectu ecclesiam parochialem in Hrubyeschow, collacionis et jurispatronatus nostri, cum illius proventibus, redditibus et obvencionibus universis per cessum et decessum, aut quocunque alio modo vacaturam, pro preposito eiusdem ecclesie incorporandam duximum et presentibus incorporamus. Ordinantes, ut prepositus quilibet pro tempore curam habeat in parochia Hrubyeschowiensi animarum cum tribus vicariis manualibus, per ipsum instituendis et destituendis, quos eciam ex suis proventibus salariare tenebitur, administrandam.

In edificacionem autem curiarum, domorum et habitacionum pro episcopo, prelatis, canonicis et vicariis ceterisque ministris ecclesie prefate nove Hrubyeschowiensi omnem locum et spacium, qui in curia nostra regia in Hrubyeschow versus occidentem ab ecclesia tenditur ${ }^{\circ}$, et certis signis distinctum et limitatum, per prefatum Dominum Paulum episcopum inter prelatos et canonicos, vicarios et ministros, reservata sibi porcione pontificali, pro suo arbitrio dividendam, donacione perpetua et irrevocabili damus, conferimus et donamus per presentes.

In cuius rei testimonium sigillum nostrum presentibus est appensum: Datum in Lublin feria quarta post festum sancti Marci Evangeliste, alias vigesima octava mensis aprilis, anno Domini millesimo quadringentesimo septuagesimo tercio, regni nostri vigesimo sexto, presentibus magnificis

- Pawet $z$ Grabowej h. Powata biskup chetmski, bral udzial w batalii wojennej pod Warnq $i$ dostal się do niewoli tureckiej. Mianowany przez króla Kazimierza Jagiellonczyka biskupem chetmskim, otrzymat prekonizację papieskq 14 VI 1463 r.; zmart 18 II 1479. Z. Szostkiewicz: dz. c. S. 70.

b W kop. 2-3 tekst: omnem locum et spatium, qui versus curiam nostram regiam in Hrubieszow versus occidentem tenditur. 
et nobilibus: Dobeslao Kmitha de Visnice Lublinensi ?. Johanne de Tharnow Woynicensi ${ }^{7 a}$, Johanne Wantrobka de Strzelce Sandeczensi ${ }^{8}$, Dobeslao de Byszow Belsensi ", Dobeslao de Kurozwyanki Rosperiensi ${ }^{10}$, Nicolao de Chranstow Chelmensi ", Stanislao de Szydlowiecz Zarnoviensi ${ }^{12}$ castellanis; Johanne de Rythwiany Regni Polonie marschalco ${ }^{13}$, Paulo de Jasszowa subdapifero Sandomiriensi et capitaneo Belsensi et Chelmensi ". Nicolao de Korythko capitaneo Lublinensi ${ }^{15}$ et aliis, quam pluribus consiliariis et militibus nostris fidelibus dilectis. Datum per manus venerabilis Sbignei de Oleschnicza scholastici et canonici Cracouiensis, Regni. Polonie vicecancellarii, nobis sincere dilecti ${ }^{16}$.

Ad relacionem eiusdem venerabilis Sbignei de Oleschnicza Regni Poloniae vicecancellarii.

$\mathrm{Nr} 2$

Kraków 26 VI 1490

Kazimierz król polski, na prosbę biskupa chelmskiego Macieja ze Starej Łomży, przenosi stolicę $i$ katedre biskupiq z Chelma do Krasnegostawu do swiq̨tyni parafialnej pw. Wszystkich Swiętych, dotychczasowe beneficjum plebana krasnostawskiego przeznacza na utrzymanie wikariuszy katedralnych, zastrzegajac ostatecznq decyzje $w$ tym względzie Stolicy Apostolskiej.

Or, Lublin. ADL Pergaminy nr 14. Pergamin $39 \times 30 \mathrm{~cm}$. Dokument częściowo $w$ górnej $i$ dolnej częsci zniszczony, brak pieczęci $i$ pasków. Na odwrocie drugq rękq $z \mathrm{XV}$ wieku: Mandatum seu litere $\mathrm{S}$. Regis Kasimiri translacionis cathedre Chelmensis episcopalis ex Chelm in Crasnystaw, oraz pózniejsze streszczenia i noty kapitulne.

Kop.: 1. Warszawa. AGAD. Metryka Koronna, t. 14 k. 369-370; tytut wpisu: Translacio cathedre de Chelm in Crasnistaw. 2. Lublin. ADL Zesp. Kapit. Chetm. nr 10. Privilegia et jura praecipua k. 22'-23'; tytui wpisu: Privilegium XII. Translatio in Crasnystaw -1490 ( $z$ XVI w.). 3. Lublin. ADL A 152. Acta visit. generalis omnium ecclesiarum dioecesis Chelmensis _ _ an. 1714-1717 k. $7^{\prime}-8^{\prime}$; tytuk wpisu: Translatio sedis episcopatus Chelmensis in civitatem Crasnostaviensem. 4. Lublin. ADL Zesp. Kapit. Chetm. nr 9. Elenchus nominum - - 1754 k. 23-24: tyt. wpisu: Privilegium XIr. Translatio in Krasnystaw.

Reg. Matr. Reg. Pol. Summ. Pars I nr 2123 s. 111.

- Dobiestaw Kmita $z$ Sobienia i Wiśnicza h. Szreniawa $(† 1478)$, kasztelan wojnicki (1460), lubelski (1464), wojew. lubelski (1474).

7a Jan Amor $z$ Tarnowa mlodszy (1420/30-1500), kasztelan sqdecki (1461) \& wojnicki (1463), wojew. sandomierski (1479) i krakowski (1491).

- Stanistaw Watroba Strzelecki h. Oksza, kasztelan sqdecki (1472), wojew. betski (1478).

9 Dobiestaw $z$ Bisiowa h. Jastrzębiec, kasztelan a następnie wojew. betski (1485);

10 Dobiestaw z Kurozwęk, zwany Lubelczyk h. Róża, kasztelan rozpierski (1472). wojew. lubelski (1484), sandomierski (1494). Zmark 1496 r. F. Kiryk: Kurozwęck - Dobiesiaw. W: Pol. Slow. Biogr. T. 16 s. 269-270.

${ }_{11}$ Chrzqstowski Mikotaj h. Kosciesza, od 1462 miecznik krakowski, od 1472 kasztelan chelmski. Zmart $27 \mathrm{~V}$ 1483. K. Piotrowicz: Chrzqstowski Mikolaj. W: Pol. Stow. Biogr. T. 3 s. 473.

12 Stanisia $w$ Szydtowiecki h. Odroważ, kasztelan żarnowiecki (1457-1475).

13 Jan $z$ Rytwian h. Jastrzębiec, kasztelan sandomierski (1459), wojew. krakowski (1475).

14 Pawet z Jasionnej (Jasieński), stolnik sandomierski, starosta betski $i$ chelmski (1468), pózniej podskarbi koronny i ziem pruskich, starosta malborski (1479) $i$ kasztelan sandomierski.

${ }_{15}$ Mikotaj Korytko, syn Tomka, zonaty $z$ Barbara Burzytiska $z$ Zakrzowor (1471), starosta lubelski.

:o Zob. przyp. 26 teksiu. 
Druk ,istotnych częsci" - P. Palka: Powstanie katedralnej kapituly \$. 24 przyp. 70.

Liter. P. Palka: dz. c. s. 24-26.

Kazimirus Dei gracia rex Polonie, magnus dux Lithuanie, Russie Prussieque dominus et heres. Significamus tenore presencium universis, quibus expedit. Cum ad Nos, ut ad Regem Christianum pertineat cultum divinum augere, illicque intendere oculos pietatis, ubi ecclesiarum honor, et presertim in quibus sedes pontificales existunt diminuitur et decrescit. Recensentesque constituciones sanctorum Patrum, quibus caveri accepimus sedes pontificales non in aliis locis, nisi insignioribus et in quibus est frequencia populi debere erigi et fundari. Cum itaque intelleximus, quomodo ecclesia Chelmensis, que est pontificalis, propter loci incommoditatem assidue deccrescat, cupientes honori, commoditati et augmenti cultus divini ipsius providere, permoti postulacionibus et vigilanti opere Reverendi Patris Domini Mathie episcopi Camenecensis et eiusdem ecclesie electi ', quantum in nobis est, sedem pontificalem ad transferendum. sive ad sedis mutacionem ex Chelm in Crasnistaw civitatem Nostram, situ et frequentia populi sedi pontificali magis occommodam et convenientem, consentimus, et in quantum Nobis convenit transferimus, auctoritate Romani Pontificis salva, ad quam sedium pontificalium mutacio pertinet pro sede pontificali sive ecclesia cathedrali ecclesiam parochialem tituli Omnium Sanctorum, quantum in Nobis est, donando proventus, quos rectores prefate parochialis in Crasnistaw, que iurispatronatus Nostri fuit, percipiebant, vicariis canonicalibus donando et incorporando, quorum vicariorum collacio ad ipsum episcopum perpetuis temporibus pertinebit. Qui vesperas, matutinum omnesque horas canonicas pro laude summi et immortalis Dei cantare voce sonora, iuxta consuetudinem aliarum ecclesiarum pontificalium, debebunt et tenebuntur.

Utque hec Nostra voluntas firmitatem habeat, presentes literas sigilli Nostri appensione iussimus communiri. Actum in convencione Cracoviensi generali, sabbato proximo post festum sancti Johannis Baptiste, anno. Domini millesimo quadringentesimo nonagesimo. Presentibus ibidem. Reverendissimis et Reverendis in Christo patribus dominis: Sbigneo ecclesie Gnesnensis archiepiscopo et primate 2 , Friderico ecclesie Cracoviensis electo confirmato ${ }^{3}$, Petro Wladislaviensi ", Uriele Posnaniensi ${ }^{5}$ et Johanne Premisliensi ${ }^{B}$ episcopis; nec non magnificis et generosis Johanne

1 Maciej ze Starej Eomży, pisarz królewski (1469-1479), biskup kamieniecki (od 1482), a następnie chetmski (od 1490). Zmart przed 12 IX 1505. I. Sulkowska-Kuraś: Maciej ze Starej Eomży. W: Pol. Stow. Biogr. t. 19 s. 36-37.

2 Zbigniew Oleśnicki, zob. dokument nr 1 przyp. 16.

3 Fryderyk Jagiellończyk, najmlodszy syn Kazimierza Jagiellonczyka i Elżbietỳ Habsburżanki, biskup elekt krakowski (1488), arcybiskup gnieźnieński (1493) $i$ kardynal Kosciola rzymskiego (1493); zmarl 14 III 1503. H. Rybus: Fryderyk Jagiellonczyk. W: Pol. Slow. Biogr. t. 7 s. $167-169$.

- Piotr $z$ Bnina, h. Łodzia, biskup przemyski (1481), przeniesiony $20 \times 1483 \mathrm{r}$. do Wloclawka, "bliski Kazimierzowi Jagiellonczykowi, a protektor $i$ przyjaciel Kallimacha". Zmart 7 III 1494. Z. Szostkiewicz: dz. c. s. 146.

- Uriel Górka h. Eodzia, w latach 1474-1479 kanclerz wielki koronny, biskup. poznarski (1479); zmart 24 I 1498. Z. Szostkiewicz: dz. c. s. 68.

- Jan $z$ Targowiska h. Tarnawa, od 1484 biskup chelmski, przeniesiony $26 \mathrm{~V}$ 1486 r. do Przemyśla. Pozostawit po sobie Roczniki. Zmart w 1492 r. Z. Szosthiewicz: dz. c. s. 88. 
Amor de Tharnow Cracoviensi ${ }^{7}$, Szpithkone de Jaraslaw Sandomiriensi ", Nicolao de Cuthno Lanciciensi et capitaneo Maiorispolonie generali. ${ }^{\circ}$, Johanne de Oporow Brestensi ${ }^{10}$, Nicolao de Dzialin Juniswladislaviensi ${ }^{12}$, Johanne de Pilcza Russie generali ${ }^{12}$, Dobeslao de Curozwanki Lublinensi ${ }^{13}$ et Nicolao Stadnyczki Belsensi palatinis ${ }^{14}$; Johanne de Ostrorog Posnaniensi ${ }^{15}$, Raphaele de Jaroslaw Sandomiriensi et regni Nostri marsalco ${ }^{16}$ Andrea de Schamotuli Callissiensi ${ }^{17}$, Nicolao de Curozwanki Siradiensi. ${ }^{18}$, Andrea de Thanczyn Woyniciensi ${ }^{10}$, Johanne Rapstynski de eadem Thanczyn Wisliciensi ${ }^{20}$, Andrea de Oleschnycza Sandeczensi ${ }^{24}$, Stanislao de Schidlowyecz Radomiensi ${ }^{22}$, Ambrosio Pampowski Rosperiensi ${ }^{28}$ castellanis, et aliis quam pluribus fide dignis testibus. Datum per manus venerabilis Gregorii de Ludbrancz Scarbimiriensis et Sti Floriani in Cleparz praepositi, regni Nostri vicecancellari ${ }^{24}$; sincere Nobis dilecti.

Relacio eiusdem venerabilis Gregorii de Ludbrancz R.P. vicecancellarii.

7 Jan Amor $z$ Tarnowa, zob. dokum. nr 1 przyp. $7 a$.

- Spytek z Jarostawia Jarosiawski (ok. 1436-1519), wojew. betski (1472), ruski (1474), sandomierski (1479), krakowski (1491), kasztelan krakowski (1501), viceregens Królestwa Polskiego (1506). W. Dworzaczek: Genealogia. Warszawa 1959 tabl. 98.

- Mikolaj z Kutna h. Ogończyk, wojew. lęczycki, pózniej poznański (1484).

10 Jan Oporowski h. Sulima, wojew. brzesko-kujawski (1490), mqż Zofii Odrowqżówny.

${ }_{11}$ Mikolaj Dzialyński $h$. Ogończyk, podkomorzy brzeski (1476), kasztelan dobrzyński (1479), wojew. inowroctawski (1484); zmart po 1502. W. Dworzaczek: dz. c. tabl. 115.

12 Jan z Pilczy, kasztelan biecki (1476), sqdecki (1479), wiślicki (1484), wojew. rusk̈i (1485), sandomierski (1496); zmart $w 1496 r$. W. Dworzaczek: dz. c. tabl. 103.

13 Dobiestaw $z$ Kurozwęk, zob. dokum. nr 1 przyp. 10.

14 Mikotaj Stadnicki, wojew. betski (1490).

15 Jan Ostroróg, kasztelan międzyrzecki (1469), poznański (1476), starosta generalny Wielkopolski (1493-1500), wojew. poznański (1500); zmari 1501. W. Dworzaczek: dz. c. tabl. 105.

18 Rafat Jakub z. Jarostawia h. Leliwa (po 1439-1492), starosta lwowski. (1465), podkomorzy przemyski (1473), marszalek Król. Pol. (1477), kasztelan sandomierski (1485); zmart $w$ 1492. W. Dworzaczek: dz. c. tabl. 98.

17 Andrzej Szamotulski h. Natęcz, kasztelan miqdzyrzecki (1473), kaliski (1487), wojew. kaliski (1501), poznański (1502); zmart 1511. W. Dworzaczek: dz. c. tabl. 104.

18 Mikolaj $z$ Kurozwę̧k h. Róża, zwany Lubelczyk, starosta szydtowski (1474), kasztelan rozpierski (1482), sieradzki (1485), wojewoda lubelski (1501), starosta sieradzki (1504); zmart przed 28 II 1507. K. Baczkowski: Kurozwęcki Mikolaj. W: Pol. Stow. Biogr. t. 16 s. $273-274$.

19 Andrzej Tęczyński h. Topór, kasztelan malogoski (1474), sqdecki (1475), wojnicki (1479); zmart $w$ 1503. W. Dworzaczek: dz. c. tabl. 94.

20 Jan z Rabsztyna h. Topor, kasztelan zawichojski (1479), wislicki (1485-90), starosta Sandomierskiej Woli; zmart 1498/99. W. Dworzaczek: dz. c. tabl. 98.

21 Andrzej $z$ Olesnicy h. Dębno, kasztelan biecki (1480), sqdecki (1484), starosta lwowski (1496); zmart 1494/1504. W. Dworzaczek: dz. c. tabl. 107.

$22 \quad$ Stanisiaw $z$ Szydtowca h. Odrowqz, zob. dokum. nr 1 przyp. 12.

23 Ambroży Pampowski, kasztelan rozpierski (1490).

24 Grzegorz Lubrański h. Godziemba, pisarz królewski (1472), kanonik sandomierski (1476), archidiakon krakowski (1477), proboszcz kapituty sw. Floriana $w$ Krakowie (1480), wielkorzqdca królewski (1479-1489), od 17 II $1784 \mathrm{r}$. podkanclerzy koronny; zmart przed 2 III 1500. K. Pieradzka: Lubrański Grzegorz. W: Pol. Slow. Biogr. t. 18 s. $80-81$. 